\title{
Macrophage Colony-stimulating Factor Is Indispensable for both Proliferation and Differentiation of Osteoclast Progenitors
}

\author{
Sakae Tanaka, ** Naoyuki Takahashi, * Nobuyuki Udagawa, * Tatsuya Tamura, * Takuhiko Akatsu, * \\ E. Richard Stanley, Takahide Kurokawa, ${ }^{*}$ and Tatsuo Suda* \\ ${ }^{*}$ Department of Biochemistry, Showa University, School of Dentistry, Tokyo 142, Japan; ${ }^{\ddagger}$ Department of Orthopedics, University of \\ Tokyo, School of Medicine, Tokyo 112, Japan; and ${ }^{\S}$ Department of Developmental Biology and Cancer, \\ Albert Einstein College of Medicine, Bronx, NY 10461
}

\begin{abstract}
The mechanism of action of macrophage colony-stimulating factor (M-CSF) in osteoclast development was examined in a co-culture system of mouse osteoblastic cells and spleen cells. In this co-culture, osteoclast-like multinucleated cells (MNCs) were formed within $6 \mathrm{~d}$ in response to $10 \mathrm{nM} 1 \alpha, 25(\mathrm{OH})_{2} \mathrm{D}_{3}$ added only for the final $2 \mathrm{~d}$ of culture. Simultaneously adding hydroxyurea for the final $2 \mathrm{~d}$ completely inhibited proliferation of cultured cells without affecting $1 \alpha, 25(\mathrm{OH})_{2} \mathrm{D}_{3}$-stimulated MNC formation. Autoradiographic examination using $\left[{ }^{3} \mathrm{H}\right]-$ thymidine revealed that osteoclast progenitors primarily proliferated during the first $4 \mathrm{~d}$, whereas their differentiation into MNCs occurred predominantly during the final $2 \mathrm{~d}$ of culture in response to $1 \alpha, 25(\mathrm{OH})_{2} D_{3}$. When anti-M-CSF antibody or anti-M-CSF receptor antibody was added either for the first $4 \mathrm{~d}$ or for the final $2 \mathrm{~d}$, the MNC formation was similarly inhibited. In co-cultures of normal spleen cells and osteoblastic cells obtained from op/op mice, which cannot produce functionally active M-CSF, the lack of M-CSF either for the first $4 \mathrm{~d}$ or for the final $2 \mathrm{~d}$ failed to form $\mathrm{MNCs}$ in response to $1 \alpha, 25(\mathrm{OH})_{2} \mathrm{D}_{3}$ added for the last $2 \mathrm{~d}$. These results clearly indicate that $\mathrm{M}$ CSF is indispensable for both proliferation of osteoclast progenitors and their differentiation into mature osteoclasts. ( $J$. Clin. Invest. 1993.91:257-263.) Key words: osteopetrotic mice - 1 $\alpha, 25$-dihydroxyvitamin $D_{3} \cdot$ anti-macrophage colony-stimulating factor antibody $\bullet$ anti-c-fms antibody
\end{abstract}

\section{Introduction}

It is well established that osteoclasts, multinucleated giant cells responsible for bone resorption, are derived from hemopoietic progenitors (1). Over the past few years, many attempts have been made to reveal the mechanism of osteoclast formation, and several in vitro systems for examining osteoclast formation have been developed (2-5). We previously reported that osteo-

Address correspondence to Dr. Tatsuo Suda, Department of Biochemistry, School of Dentistry, Showa University, 1-5-8 Hatanodai, Shinagawa-ku, Tokyo 142, Japan.

Received for publication 26 May 1992 and in revised form $21 \mathrm{Au}$ gust 1992.

\section{J. Clin. Invest.}

(C) The American Society for Clinical Investigation, Inc.

0021-9738/93/01/0257/07 \$2.00

Volume 91, January 1993, 257-263 clast-like multinucleated cells (MNCs) ${ }^{1}$ were formed when mouse spleen cells were co-cultured with primary osteoblastic cells, obtained from mouse calvaria, in the presence of bone-resorbing agents such as $1 \alpha, 25(\mathrm{OH})_{2} \mathrm{D}_{3}, \mathrm{PTH}$, and PGs (6). Like authentic osteoclasts, MNCs formed in our co-culture system were positive for tartrate-resistant acid phosphatase (TRAP), possessed a number of calcitonin receptors, had ruffled borders and clear zones, and formed resorption pits on dentine slices (6).

In a previous report (7), we showed that not only mouse spleen cells but also blood monocytes and alveolar macrophages formed single cell-derived colonies on the marrow-derived stromal ST2 cell layers. All of the colonies consisted of mainly nonspecific esterase (a macrophage marker enzyme)-positive cells, and TRAP-positive cells also appeared in the colonies in response to $1 \alpha, 25(\mathrm{OH})_{2} \mathrm{D}_{3}$ and dexamethasone (7). These results suggest that osteoclasts are derived from cells of the monocyte-macrophage lineage. This hypothesis is supported by the recent finding that osteoclast deficiency in osteopetrotic $(o p / o p)$ mice is due to an inability to produce functionally active macrophage colony-stimulating factor (M-CSF, also known as colony-stimulating factor-1) $(8,9)$. Yoshida et al. clearly demonstrated an extra thymidine insertion at bp No. 262 in the coding region of the M-CSF gene in $o p / o p$ mice, which generated a TGA stop codon, 21 bp downstream (10). Almost simultaneously, it was shown that administration of recombinant human M-CSF to op/op mice cured their osteopetrotic bone disorders (11). This in vivo observation was quickly confirmed by Kodama et al. (12) and Wiktor-Jedrzejczak et al. (13). We also reported that osteoblastic cells obtained from $o p / o p$ mice could not support osteoclast differentiation in co-cultures with normal spleen cells (14). Adding M-CSF together with $1 \alpha, 25(\mathrm{OH})_{2} \mathrm{D}_{3}$ induced osteoclast-like MNCs in co-cultures with $o p / o p$ osteoblastic cells (14). These findings strongly indicate that M-CSF produced by osteoblastic cells plays a critical role in osteoclast development.

In 1986, MacDonald et al. reported that M-CSF stimulated osteoclast-like cell formation in human bone marrow cultures (15). More recently, we demonstrated that M-CSF effectively stimulates proliferation of osteoclast progenitors, but that this effect can be duplicated by other hemopoietic growth factors such as GM-CSF and IL-3 (16). These findings support the hypothesis that M-CSF plays an important role not only in the

1. Abbreviations used in this paper: M-CSF, macrophage colony-stimulating factor; MNCs, multinucleated cells; TRAP, tartrate-resistant acid phosphatase. 
growth of osteoclast progenitors but also in their terminal differentiation into mature osteoclasts.

In the present study, we have attempted to separate the process of osteoclast development into two phases, proliferative phase and differentiation phase, to elucidate the mechanism of action of M-CSF in osteoclast development. We report here that M-CSF is critical not only for proliferation of osteoclast progenitors but also for their terminal differentiation into mature osteoclasts.

\section{Methods}

Antibodies and chemicals. Goat anti-mouse M-CSF antiserum (antiM-CSF antibody) (17) and anti-mouse c- $f m s / M-C S F$ receptor antiserum (anti-c- $f m s$ antibody) (18) were prepared as described. These antibodies added at $0.1 \%$ were sufficient to inhibit colony formation of mouse marrow cells induced by murine M-CSF. Anti-mouse GM-CSF polyclonal antibody (anti-GM-CSF antibody) was kindly provided by Sumitomo Pharmaceutical Co. (Osaka, Japan). This antibody added at $0.4 \%$ completely inhibited the DNA synthesis in mouse marrow cells induced by $2 \mathrm{ng} / \mathrm{ml}$ of murine GM-CSF. $1 \alpha, 25(\mathrm{OH})_{2} \mathrm{D}_{3}$ was purchased from Philips-Duphar (Amsterdam, The Netherlands). Salmon calcitonin was kindly supplied by Chugai Pharmaceutical Co. (Tokyo, Japan ). $\left[{ }^{125} \mathrm{I}\right]$ salmon calcitonin was prepared as previously described (19). The specific activity of the product was $18.5 \mathrm{TBq} / \mathrm{mmol}$. Hydroxyurea was obtained from Sigma Chemical Co. (St. Louis, MO). $\left[{ }^{3} \mathrm{H}\right]$ Thymidine (specific activity, $3.11 \mathrm{TBq} / \mathrm{mmol}$ ) was purchased from Amersham International plc. (Amersham, UK). FCS was obtained from Gibco Laboratories (Grand Island, NY). $\alpha$-MEM was purchased from Flow Laboratories, Inc. (McLean, VA). Culture dishes and plates were obtained from Corning Glass Inc. (Corning, NY). Recombinant human M-CSF was kindly provided by Morinaga Milk Co. (Tokyo, Japan).

Cell cultures. Male mice (7- to 9-wk-old) and newborn mice, ddy strain, were obtained from Shizuoka Laboratories Animal Center (Shizuoka, Japan). Primary osteoblastic cells were prepared from newborn mouse calvaria as previously reported (6). Male and female heterozygotes $(+/ o p)$ of $\mathrm{B} 6 \mathrm{C} 3$ mice were obtained from The Jackson Laboratory (Bar Harbor, ME). A quarter of their littermates are expected to be osteopetrotic $(o p / o p)$. The $o p / o p$ homozygotes were radiologically distinguished at birth from phenotypically normal, +/? siblings. Osteoblastic cells of $o p / o p$ mice were obtained according to the method previously reported (14). In short, calvaria of $o p / o p$ mice were cultured in type I collagen gels, and outgrowing cells were used as $o p / o p$ osteoblastic cells. Spleen cells were obtained from splenic tissues of 7 to 9-wk-old ddy mice. Osteoblastic cells $\left(1 \times 10^{4}\right.$ cells $/$ well $)$ and spleen cells $\left(7.5 \times 10^{5}\right.$ cells $/$ well $)$ were co-cultured for $6 \mathrm{~d}$ in $\alpha$-MEM containing $10 \% \mathrm{FCS}$ in the presence or absence of $10 \mathrm{nM} 1 \alpha, 25(\mathrm{OH})_{2} \mathrm{D}_{3}$ in 24-well plates $(0.5 \mathrm{ml} /$ well $)$. Some cultures were treated with $10 \mathrm{nM}$ $1 \alpha, 25(\mathrm{OH})_{2} \mathrm{D}_{3}$ only for the final $2 \mathrm{~d}$ of the 6 -d co-culture period. To inhibit DNA synthesis, hydroxyurea $(0.2-1.0 \mathrm{mM})$ was added to the co-cultures together with $1 \alpha, 25(\mathrm{OH})_{2} \mathrm{D}_{3}(10 \mathrm{nM})$ for the final $2 \mathrm{~d}$ of culture. In some experiments, co-cultures were treated on days $0-4$ or days 4-6 with either anti-M-CSF antibody, anti-c- $f m s$ antibody, or anti-GM-CSF antibody. In other experiments, osteoblastic cells obtained from $o p / o p$ calvaria were co-cultured with normal spleen cells from ddy mice in the presence of $1 \alpha, 25(\mathrm{OH})_{2} \mathrm{D}_{3}$ added only for the last $2 \mathrm{~d}$. Recombinant human M-CSF was added at $100 \mathrm{ng} / \mathrm{ml}$ to the cultures either for the first $4 \mathrm{~d}$, for the final $2 \mathrm{~d}$, or throughout the entire 6-d co-culture period. In some cultures, $1 \mathrm{mM}$ hydroxyurea was added to the co-culture for the final $2 \mathrm{~d}$. All cultures were maintained at $37^{\circ} \mathrm{C}$ in a humidified atmosphere of $5 \% \mathrm{CO}_{2}$ in air.

Identification of the osteoclast-like MNCs. After being cultured for $6 \mathrm{~d}$, cells were fixed and stained for TRAP in accordance with a previ- ously reported method (20). TRAP-positive cells with three or more nuclei were counted as MNCs. Expression of calcitonin receptors was also assessed by autoradiography using [ $\left.{ }^{125} \mathrm{I}\right]$ salmon calcitonin as described previously (21). More than $95 \%$ of the TRAP-positive MNCs formed in the co-cultures treated with $1 \alpha, 25(\mathrm{OH})_{2} \mathrm{D}_{3}$ for the final $2 \mathrm{~d}$ of culture showed specific binding of labeled calcitonin (data not included). Therefore, we referred TRAP-positive MNCs formed in our co-culture system to osteoclast-like MNCs in this article.

Assessment of cell proliferation. We evaluated cell proliferation using two experimental procedures; one involved determining $\left[{ }^{3} \mathrm{H}\right]-$ thymidine incorporation into acid- insoluble fractions of cultured cells, and the other was autoradiographic observation using $\left[{ }^{3} \mathrm{H}\right]$ thymidine. In the experiment assessing $\left[{ }^{3} \mathrm{H}\right]$ thymidine incorporation, the radioisotope $\left(3.7 \times 10^{4} \mathrm{~Bq} / 0.5 \mathrm{ml}\right)$ was added to co-cultures on day 6 . After incubation for $12 \mathrm{~h}$, cells were washed twice with ice-cold PBS. The radioactivity incorporated into TCA-insoluble fractions was counted in scintillation fluid (ACS II; Amersham Corp., Arlington Heights, IL). For autoradiographic studies, co-cultures were performed on coverslips ( $13.5 \mathrm{~mm}$; Sumitomo Bakelite Co., Tokyo, Japan) placed in 24-well plates. $\left[{ }^{3} \mathrm{H}\right]$ Thymidine $\left(3.7 \times 10^{4} \mathrm{~Bq} / 0.5 \mathrm{ml}\right)$ was added to the co-cultures for $12 \mathrm{~h}$ either on day 3 or day 5 . In some experiments, co-cultures were treated with $1 \mathrm{mM}$ hydroxyurea together with $1 \alpha, 25(\mathrm{OH})_{2} \mathrm{D}_{3}$ for the final $2 \mathrm{~d}$ of culture to inhibit cell proliferation. 1 $\mathrm{mM}$ hydroxyurea was sufficient to inhibit completely DNA synthesis in our co-cultures. After being cultured for $6 \mathrm{~d}$, cells were fixed, stained for TRAP, and processed for autoradiography as described previously (21). Nuclei which contained $>50$ grains were counted as labeled nuclei.

Statistical analysis. Each series of experiments was repeated at least three times. The results obtained from a typical experiment were expressed as the means \pm SEM ( standard error of the mean) of quadruplicate cultures. Significant differences were determined using Student's $t$ test.

\section{Results}

When mouse spleen cells were co-cultured for $6 \mathrm{~d}$ with mouse osteoblastic cells in the presence of $10 \mathrm{nM} 1 \alpha, 25(\mathrm{OH})_{2} \mathrm{D}_{3}$, a number of osteoclast-like MNCs were formed in response to the vitamin (Fig. 1). Adding $1 \alpha, 25(\mathrm{OH})_{2} \mathrm{D}_{3}$ only for the final $2 \mathrm{~d}$ of the 6-d co-culture period also induced osteoclast-like MNC formation, though the number of osteoclast-like MNCs formed was slightly smaller than that observed when the vitamin was added throughout the co-culture period (Fig. 1). A small number of osteoclast-like MNCs were also formed in control co-cultures after the cells had been cultured for $6 \mathrm{~d}$ without $1 \alpha, 25(\mathrm{OH})_{2} \mathrm{D}_{3}$, but no osteoclast-like MNCs appeared on day 4 even in co-cultures treated with $1 \alpha, 25(\mathrm{OH})_{2} \mathrm{D}_{3}$ (Fig. 1). We repeated these experiments 18 times, and obtained similar results in 15 of them. In the other three experiments, only a few osteoclast-like MNCs were formed on day 6 in response to $1 \alpha, 25(\mathrm{OH})_{2} \mathrm{D}_{3}$ even when $1 \alpha, 25(\mathrm{OH})_{2} \mathrm{D}_{3}$ was added throughout the entire 6-d co-culture period. These results indicate that osteoclast precursors differentiate into osteoclasts during the final $2 \mathrm{~d}$ of culture (days $4-6)$ in response to $1 \alpha, 25(\mathrm{OH})_{2} \mathrm{D}_{3}$.

To determine whether cell growth must occur during terminal differentiation of osteoclast progenitors, we examined osteoclast-like MNC formation in the presence of hydroxyurea. Adding hydroxyurea together with $10 \mathrm{nM} 1 \alpha, 25(\mathrm{OH})_{2} \mathrm{D}_{3}$ for the final $2 \mathrm{~d}$ of culture dose-dependently inhibited $\left[{ }^{3} \mathrm{H}\right]-$ thymidine incorporation into acid-insoluble fractions of cultured cells (Table I). $1 \mathrm{mM}$ hydroxyurea was sufficient to in- 


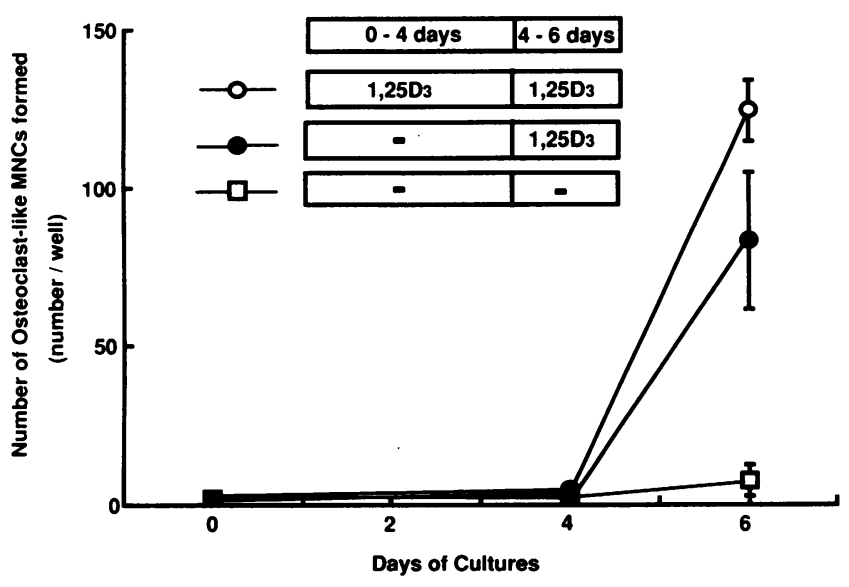

Figure 1. Time course of changes in osteoclast-like MNC formation in co-cultures of osteoblastic cells and spleen cells in the presence or absence of $1 \alpha, 25(\mathrm{OH})_{2} \mathrm{D}_{3}$. Mouse primary osteoblastic cells and spleen cells were co-cultured for $6 \mathrm{~d}$ without $(\square)$ or with $1 \alpha, 25(\mathrm{OH})_{2} \mathrm{D}_{3}\left(1,25 \mathrm{D}_{3}\right) .1 \alpha, 25(\mathrm{OH})_{2} \mathrm{D}_{3}$ was added at $10 \mathrm{nM}$ either throughout the 6-d co-culture period $(0)$ or only for the final $2 \mathrm{~d}$ of culture $(\bullet)$. The results are expressed as the means \pm SEM of four cultures.

hibit completely DNA synthesis. Nevertheless, osteoclast-like MNC formation induced by $1 \alpha, 25(\mathrm{OH})_{2} \mathrm{D}_{3}$ was not affected by simultaneously adding hydroxyurea (Table I). No osteoclast-like MNCs were formed when hydroxyurea was added at $1 \mathrm{mM}$ for the first $4 \mathrm{~d}$ (data not included). Autoradiographic studies also showed that when $\left[{ }^{3} \mathrm{H}\right]$ thymidine was added for 12 $h$ on day 5 to co-cultures, which had been treated with hydroxyurea together with $1 \alpha, 25(\mathrm{OH})_{2} \mathrm{D}_{3}$ for the final $2 \mathrm{~d}$ of culture, none of the nuclei in the osteoclast-like MNCs were labeled with $\left[{ }^{3} \mathrm{H}\right]$ thymidine on day 6 (Fig. $2 \mathrm{C}$ ). This further confirmed that the induction of differentiation by $1 \alpha, 25(\mathrm{OH})_{2} \mathrm{D}_{3}$ of osteoclast precursors into osteoclast-like MNCs occurs during days 4-6, and that this process is absolutely independent of cell proliferation.

We next compared the relative proliferation activity of the osteoclast progenitors on days 3 and 5 of co-culture. The cocultured cells were labeled with $\left[{ }^{3} \mathrm{H}\right]$ thymidine on day 3 , and then were treated with hydroxyurea together with $1 \alpha, 25(\mathrm{OH})_{2} \mathrm{D}_{3}$ for the final $2 \mathrm{~d}$ to inhibit cell proliferation after labeling. About a half $(51 \%)$ of the nuclei in the osteoclast-like MNCs formed in cultures given $\left[{ }^{3} \mathrm{H}\right]$ thymidine on day 3 were densely labeled (Table II and Fig. $2 A$ ). Many osteoblastic cells also contained labeled nuclei. When the labeling was performed on day 5 in the absence of hydroxyurea, only $7.3 \%$ of the nuclei in osteoclast-like MNCs formed in response to $1 \alpha, 25(\mathrm{OH})_{2} \mathrm{D}_{3}$ were labeled with $\left[{ }^{3} \mathrm{H}\right]$ thymidine (Fig. $2 B$ and Table II). The number of osteoclast-like MNCs formed in cocultures labeled with $\left[{ }^{3} \mathrm{H}\right]$ thymidine on day 3 was much less, as compared with the number obtained in co-cultures labeled on day 5 (Table II). Even when hydroxyurea was not added to the co-cultures labeled with $\left[{ }^{3} \mathrm{H}\right]$ thymidine on day 3 , the number of osteoclast-like MNCs formed in response to $1 \alpha, 25(\mathrm{OH})_{2} \mathrm{D}_{3}$ was similarly decreased (data not shown). This suggests that in the proliferative phase, osteoclast progenitors are highly sensitive to radioactive thymidine. From these re- sults, we concluded that osteoclast progenitors mostly proliferate during the first 4 days (proliferative phase) and that their differentiation into osteoclast-like MNCs occurs preferentially during the final $2 \mathrm{~d}$ of culture in the absence of appreciable DNA synthesis (differentiation phase).

To examine how M-CSF is involved in osteoclast development, co-cultures were treated with anti-M-CSF antibody, anti-c- $f m s$ antibody, and anti-GM-CSF antibody during the proliferative phase (the first $4 \mathrm{~d}$ ) or during the differentiation phase (the final $2 \mathrm{~d}$ ). Fig. 3 shows the dose-response effect of these antibodies added either during the first $4 \mathrm{~d}$ (Fig. $3 \mathrm{~A}$ ) or during the final $2 \mathrm{~d}$ (Fig. $3 \mathrm{~B}$ ) on osteoclast-like MNC formation induced by $1 \alpha, 25(\mathrm{OH})_{2} \mathrm{D}_{3}$. In either case, anti-M-CSF antibody and anti-c- $f m s$ antibody inhibited osteoclast-like MNC formation dose-dependently (Fig. 3, $A$ and $B$ ). The appearance of TRAP-positive mononuclear cells (possibly precursors of osteoclast-like MNCs) was also suppressed by treatment with the respective antibodies (data not included). In contrast, neither osteoclast-like MNC formation nor TRAP-positive mononuclear cell formation induced by $1 \alpha, 25(\mathrm{OH})_{2} \mathrm{D}_{3}$ was inhibited by adding anti-GM-CSF antibody both in the proliferative phase and differentiation phase (Fig. 3, $A$ and $B$ ). In either case, preimmune serum had no inhibitory effect on osteoclast-like MNC formation (data not shown).

To further investigate the importance of M-CSF in osteoclast development, we performed co-cultures of normal spleen cells obtained from ddy mice and osteoblastic cells from $o p / o p$ mice, which do not produce functionally active M-CSF. When recombinant human M-CSF was present at $100 \mathrm{ng} / \mathrm{ml}$ throughout the 6-d co-culture period, osteoclast-like MNCs

Table I. Effects of Hydroxyurea on $\left[{ }^{3} H\right]$ Thymidine Incorporation into Acid-insoluble Fractions and on Osteoclast-like MNC Formation in Co-cultures of Mouse Osteoblastic Cells and Spleen Cells

\begin{tabular}{|c|c|c|}
\hline Treatment & $\begin{array}{l}{\left[{ }^{3} \mathrm{H}\right] \text { Thymidine }} \\
\text { incorporation }\end{array}$ & $\begin{array}{l}\text { Number of } \\
\text { TRAP-positive } \\
\text { MNCs formed }\end{array}$ \\
\hline & cpm/well & number/well \\
\hline Vehicle & $120,320 \pm 15,677$ & $28 \pm 5^{*}$ \\
\hline $1 \alpha, 25(\mathrm{OH})_{2} \mathrm{D}_{3}(10 \mathrm{nM})$ & $91,030 \pm 9,176$ & $144 \pm 2$ \\
\hline \multicolumn{3}{|l|}{$1 \alpha, 25(\mathrm{OH})_{2} \mathrm{D}_{3}(10 \mathrm{nM})$} \\
\hline + hydroxyurea $(0.2 \mathrm{mM})$ & $14,364 \pm 2,640^{*}$ & $137 \pm 9$ \\
\hline \multicolumn{3}{|l|}{$1 \alpha, 25(\mathrm{OH})_{2} \mathrm{D}_{3}(10 \mathrm{nM})$} \\
\hline + hydroxyurea $(1.0 \mathrm{mM})$ & $2,133 \pm 374^{*}$ & $132 \pm 17$ \\
\hline
\end{tabular}

Mouse primary osteoblastic cells and spleen cells were co-cultured in the absence of $1 \alpha, 25(\mathrm{OH})_{2} \mathrm{D}_{3}$ for the first $4 \mathrm{~d}$ then without or with $10 \mathrm{nM} 1 \alpha, 25(\mathrm{OH})_{2} \mathrm{D}_{3}$ for an additional $2 \mathrm{~d}$. Hydroxyurea was added to the co-cultures at $0.2 \mathrm{mM}$ or $1.0 \mathrm{mM}$ for the final $2 \mathrm{~d}$ of culture together with $10 \mathrm{nM} 1 \alpha, 25(\mathrm{OH})_{2} \mathrm{D}_{3}$. $\left[{ }^{3} \mathrm{H}\right]$ Thymidine $\left(3.7 \times 10^{4} \mathrm{~Bq} /\right.$ $0.5 \mathrm{ml}$ ) was added to some of the cultures on day 6 . After incubation for $12 \mathrm{~h}$, the radioactivity incorporated into TCA-insoluble fractions was counted. In the remaining cultures, cells were fixed and stained for TRAP on day 6, and TRAP-positive MNCs were counted. ${ }^{*}$ Significantly different from the co-cultures treated with $1 \alpha, 25(\mathrm{OH})_{2} \mathrm{D}_{3}$ alone, $P<0.01$. 


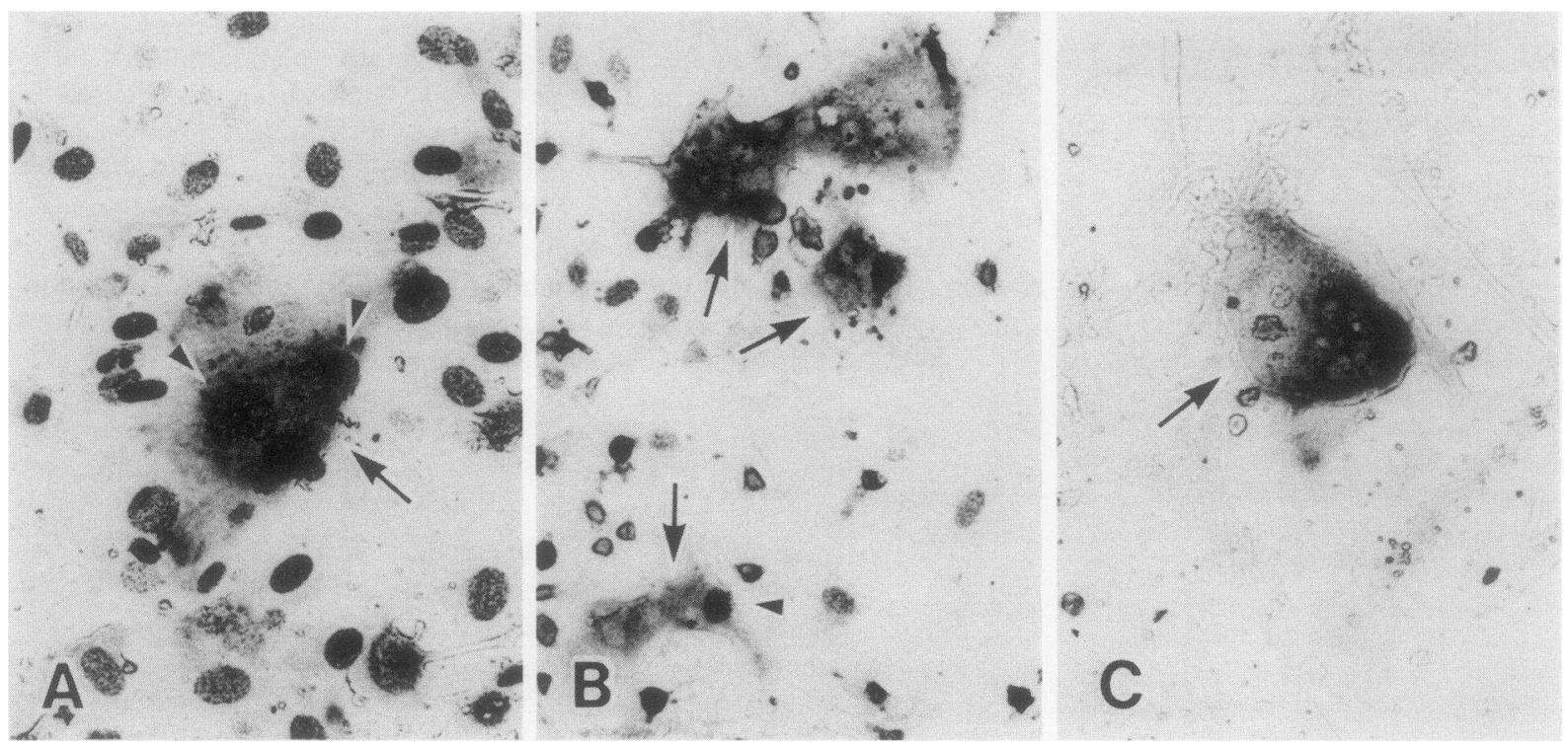

Figure 2. Autoradiography of $\left[{ }^{3} \mathrm{H}\right]$ thymidine incorporation into co-cultures of osteoblastic cells and spleen cells. Mouse primary osteoblastic cells and spleen cells were co-cultured in the absence of $1 \alpha, 25(\mathrm{OH})_{2} \mathrm{D}_{3}$ for the first $4 \mathrm{~d}$ then with $10 \mathrm{nM} 1 \alpha, 25(\mathrm{OH})_{2} \mathrm{D}_{3}$ for an additional $2 \mathrm{~d}$. [ $\left.{ }^{3} \mathrm{H}\right]-$ thymidine $\left(3.7 \times 10^{4} \mathrm{~Bq} / 0.5 \mathrm{ml}\right)$ was added for $12 \mathrm{~h}$ on day $3(A)$ or day $5(B$ and $C)$. In experiments $(A)$ and $(C)$, hydroxyurea was added at $1 \mathrm{mM}$ for the final $2 \mathrm{~d}$ of culture together with $1 \alpha, 25(\mathrm{OH})_{2} \mathrm{D}_{3}$. After being cultured for $6 \mathrm{~d}$, cells were fixed, stained for TRAP, and processed for autoradiography. Arrows and arrow heads indicate TRAP-positive MNCs and their $\left[{ }^{3} \mathrm{H}\right]$ thymidine-labeled nuclei, respectively.

were formed in response to $1 \alpha, 25(\mathrm{OH})_{2} \mathrm{D}_{3}$, which was added only for the final $2 \mathrm{~d}$ (Fig. 4). Osteoclast-like MNCs were also formed even in the presence of hydroxyurea, which was added at $1 \mathrm{mM}$ for the final $2 \mathrm{~d}$ together with $1 \alpha, 25(\mathrm{OH})_{2} \mathrm{D}_{3}$ (Fig. 4). However, lack of M-CSF either for the first $4 \mathrm{~d}$ (proliferative phase) or for the final $2 \mathrm{~d}$ (differentiation phase) failed to form osteoclast-like MNCs almost completely (Fig. 4). These results demonstrate that M-CSF is required both in the proliferative phase and in the differentiation phase of osteoclast development.

Table II. Labeling of Nuclei with $\left[{ }^{3} H\right]$ Thymidine in TRAPpositive MNCs Formed in Co-cultures of Mouse Osteoblastic Cells and Spleen Cells

\begin{tabular}{ccccc}
\hline $\begin{array}{c}\text { Day of } \\
\text { [ } \begin{array}{c}\text { H]thymidine } \\
\text { labeling }\end{array}\end{array}$ & $\begin{array}{c}\text { Number } \\
\text { of nuclei } \\
\text { scored }^{*}\end{array}$ & $\begin{array}{c}\text { Number } \\
\text { of nuclei } \\
\text { labeled }\end{array}$ & $\begin{array}{c}\text { Percentage } \\
\text { of labeled } \\
\text { nuclei }\end{array}$ & $\begin{array}{c}\text { Number of } \\
\text { TRAP-positive } \\
\text { MNCs/coverslip }\end{array}$ \\
\hline Day 3 & 141 & 72 & 51 & $43 \pm 4.8$ \\
Day 5 & 804 & 59 & 7.3 & $233 \pm 15$ \\
\hline
\end{tabular}

Mouse primary osteoblastic cells and spleen cells were co-cultured on coverslips in the absence of $1 \alpha, 25(\mathrm{OH})_{2} \mathrm{D}_{3}$ for the first $4 \mathrm{~d}$ then with $10 \mathrm{nM} 1 \alpha, 25(\mathrm{OH})_{2} \mathrm{D}_{3}$ for an additional $2 \mathrm{~d}$. $\left[{ }^{3} \mathrm{H}\right]$ Thymidine $\left(3.7 \times 10^{4}\right.$ $\mathrm{Bq} / 0.5 \mathrm{ml}$ ) was added for $12 \mathrm{~h}$ on day 3 or day 5 . The co-cultures labeled on day 3 were treated with $1 \mathrm{mM}$ hydroxyurea for the final 2 $\mathrm{d}$ of culture to inhibit cell proliferation after labeling. After being cultured for $6 \mathrm{~d}$, cells were fixed, stained for TRAP, and processed for autoradiography. * Only nuclei of TRAP-positive MNCs which could be distinguished from those of TRAP-negative osteoblastic cells were scored. ${ }^{\ddagger}$ Nuclei containing $>50$ grains were counted as labeled nuclei.

\section{Discussion}

The present study clearly shows that the 6-d culture period of our co-culture system can be separated into two phases: the first $4 \mathrm{~d}$, in which the proliferation of osteoclast progenitors primarily occurs, and the final $2 \mathrm{~d}$, in which their differentiation into mature osteoclasts is predominant. First, no TRAPpositive osteoclast-like MNCs appeared on day 4 even in the presence of $1 \alpha, 25(\mathrm{OH})_{2} \mathrm{D}_{3}$ (Fig. 1). Second, TRAP-positive MNCs were formed during the final $2 \mathrm{~d}$ of culture in response to $1 \alpha, 25(\mathrm{OH})_{2} \mathrm{D}_{3}$ even under conditions in which DNA synthesis was almost completely inhibited by the addition of $1 \mathrm{mM}$ hydroxyurea (Table I). Third, the labeling index of $\left[{ }^{3} \mathrm{H}\right]-$ thymidine in the nuclei of TRAP-positive MNCs was $51 \%$ when $\left[{ }^{3} \mathrm{H}\right]$ thymidine was added on day 3 and only $7 \%$ on day 5 (Fig. 2 and Table II). It should be noted that the number of osteoclast-like MNCs counted on day 6 in co-cultures labeled with $\left[{ }^{3} \mathrm{H}\right]$ thymidine on day 3 was markedly decreased as compared with the number obtained in co-cultures labeled on day 5 . This suggests that osteoclast progenitors are highly sensitive to $\left[{ }^{3} \mathrm{H}\right]$ thymidine during the proliferative phase. Adding hydroxyurea at $1 \mathrm{mM}$ for the first $4 \mathrm{~d}$ inhibited osteoclast-like MNC formation completely (data not shown). In agreement with our findings, Scheven et al. (22) reported that proliferation of osteoclast progenitors in embryonic mouse metatarsal bones was sensitive to ionizing irradiation, but the formation of multinucleated osteoclasts was relatively resistant.

Using a modified co-culture system, we examined the role of M-CSF in osteoclast development. M-CSF is a growth factor responsible for proliferation, differentiation and survival of hemopoietic cells of the monocyte-macrophage lineage (23). Treatment of co-cultures with anti-M-CSF antibody for the first $4 \mathrm{~d}$ dose-dependently inhibited osteoclast-like MNC for- 


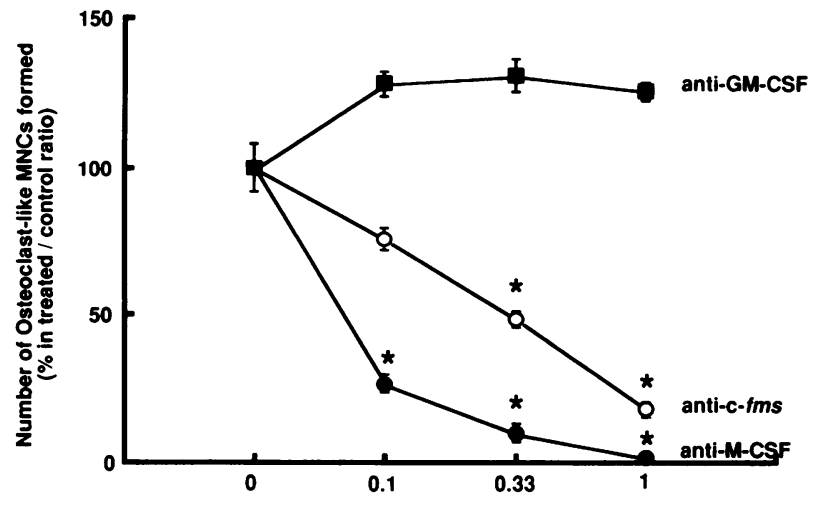

A

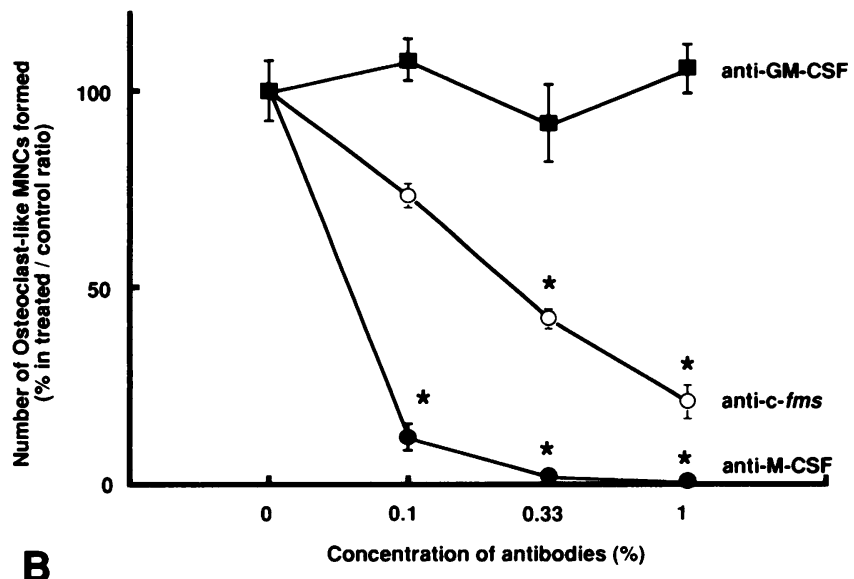

Figure 3. Dose-response effects of anti-M-CSF, anti-c- $f m s$ and antiGM-CSF antibodies on osteoclast-like MNC formation induced by $1 \alpha, 25(\mathrm{OH})_{2} \mathrm{D}_{3}$ in co-cultures of osteoblastic cells and spleen cells. Mouse primary osteoblastic cells and spleen cells were co-cultured in the absence of $1 \alpha, 25(\mathrm{OH})_{2} \mathrm{D}_{3}$ for the first $4 \mathrm{~d}$ then with $10 \mathrm{nM}$ $1 \alpha, 25(\mathrm{OH})_{2} \mathrm{D}_{3}$ for an additional $2 \mathrm{~d}$. Increasing concentrations of anti-M-CSF antibody $(\bullet)$, anti-c- $f m s$ antibody $(0)$ or anti-GM-CSF antibody $(\square)$ were added either for the first $4 \mathrm{~d}(A)$ or for the final $2 \mathrm{~d}(B)$ of culture. After $6 \mathrm{~d}$ of culture, TRAP-positive MNCs were counted. The results are expressed as the percentages (the means \pm SEM of four cultures) of TRAP-positive MNCs formed in experimental cultures to those in control cultures treated with $1 \alpha, 25(\mathrm{OH})_{2} \mathrm{D}_{3}$ alone for the final $2 \mathrm{~d}$ of culture. Numbers of TRAP-positive MNCs formed in the control cultures for the respective antibody experiments were $121 \pm 9.6$ for anti-M-CSF, $172 \pm 12$ for anti-c- $f m s$, and $164 \pm 15$ for anti-GM-CSF experiments (the means \pm SEM/well of four cultures). *Significantly different from the cultures treated with $1 \alpha, 25(\mathrm{OH})_{2} \mathrm{D}_{3}$ alone, $P<0.01$.

mation induced by $1 \alpha, 25(\mathrm{OH})_{2} \mathrm{D}_{3}$, which was added for the final $2 \mathrm{~d}$ of culture (Fig. $3 \mathrm{~A}$ ). This indicates that M-CSF is necessary for promoting proliferation of osteoclast progenitors. Similar results were obtained in experiments with anti-c- $f m s$ antibody, but anti-GM-CSF antibody had no inhibitory effect (Fig. $3 A$ ). We previously reported that M-CSF was the most efficient stimulator of osteoclast progenitor proliferation, but that GM-CSF and IL-3 could be substituted for M-CSF to some extent in producing this effect in two-step co-culture sys- tem (16). However, in the present study, anti-GM-CSF antibody added during the proliferative phase failed to suppress osteoclast formation. We also confirmed that the proliferation of macrophages maintained on the $o p / o p$ osteoblastic cells was very poor (unpublished observation), though GM-CSF was normally produced by $o p / o p$ osteoblastic cells (8). These results indicate that in this modified co-culture system, osteoclast progenitors proliferated preferentially in response to M-CSF. This notion is in accordance with that of Corboz et al. (24), who reported that irradiation inhibited the M-CSF-induced bone resorption in a mouse metatarsal bone culture system. It is therefore concluded that M-CSF is important as a proliferation factor of osteoclast progenitors.

Addition of either anti-M-CSF antibody or anti-c- $f m s$ antibody to co-cultures during the differentiation phase also suppressed the appearance of TRAP-positive MNCs dose-dependently (Fig. $3 \mathrm{~B}$ ). As was shown in the experiments with hydroxyurea, differentiation of precursor cells into osteoclast-like MNCs occurred by a mechanism independent of cell growth during the final $2 \mathrm{~d}$ of culture (Fig. 1 and Table I). Anti-GMCSF antibody added during the differentiation phase did not affect osteoclast-like $\mathrm{MNC}$ induction by $1 \alpha, 25(\mathrm{OH})_{2} \mathrm{D}_{3}$ (Fig. $3 B$ ).

Experiments using osteoblastic cells obtained from $o p / o p$ mouse calvaria made our conclusion more convincing. The $o p / o p$ osteoblastic cells do not produce functionally active $\mathrm{M}$ CSF. No osteoclast-like MNCs were formed in co-cultures of $o p / o p$ osteoblastic cells and normal spleen cells even in the presence of $1 \alpha, 25(\mathrm{OH})_{2} \mathrm{D}_{3}$. Adding recombinant human $\mathrm{M}$ CSF ( $100 \mathrm{ng} / \mathrm{ml})$ throughout the $6-\mathrm{d}$ culture period and $1 \alpha, 25(\mathrm{OH})_{2} \mathrm{D}_{3}$ during the final $2 \mathrm{~d}$ induced osteoclast-like MNC formation. A number of osteoclast-like MNCs were simi-

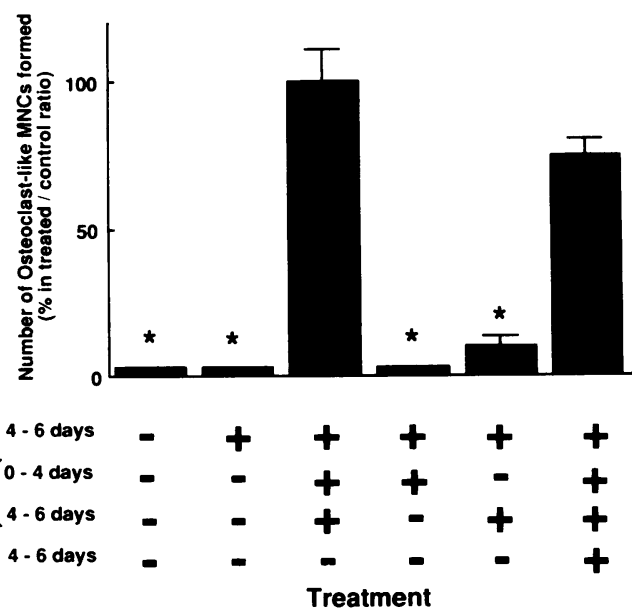

Figure 4. Osteoclast-like MNC formation in co-cultures of osteoblastic cells obtained from $o p / o p$ mice and normal mouse spleen cells obtained from ddy mice. Cells were cultured in the absence of $1 \alpha, 25(\mathrm{OH})_{2} \mathrm{D}_{3}$ for the first $4 \mathrm{~d}$ then with $10 \mathrm{nM} 1 \alpha, 25(\mathrm{OH})_{2} \mathrm{D}_{3}$ for an additional $2 \mathrm{~d}$. Recombinant human M-CSF (rhM-CSF) was added at $100 \mathrm{ng} / \mathrm{ml}$ to the cultures either for the first $4 \mathrm{~d}$, for the final $2 \mathrm{~d}$, or throughout the entire culture period. Hydroxyurea was added to the cultures only for the final $2 \mathrm{~d}$ together with $1 \alpha, 25(\mathrm{OH})_{2} \mathrm{D}_{3}$ in the presence of rhM-CSF throughout the 6-d culture period. *Significantly different from the cultures treated with rhM-CSF which was present throughout the culture period, $P<0.01$. 
larly formed in response to $1 \alpha, 25(\mathrm{OH})_{2} \mathrm{D}_{3}$ even in the presence of $1 \mathrm{mM}$ hydroxyurea which was added during the last $2 \mathrm{~d}$ (Fig. 4). In contrast, lack of M-CSF either in the proliferative phase or in the differentiation phase failed to form osteoclastlike MNCs (Fig. 4). These results clearly demonstrate that MCSF plays a critical role in inducing not only proliferation of osteoclast progenitors but also their differentiation into mature osteoclasts. This is consistent with the finding of Hattersley et al., who reported that GM-CSF increased the appearance of F4/80-positive macrophages but not osteoclasts in co-cultures of $o p / o p$ osteoblastic cells and normal spleen cells (25).

The action of M-CSF has been reported to be mediated by a specific receptor encoded by the $\mathrm{c}-\mathrm{fms}$ protooncogene, which exhibits tyrosine kinase activity (26). Kodama et al. reported that M-CSF receptors existed in osteoclast-like MNCs and their precursors but not in osteoblastic cells (27). Therefore, in our co-cultures of osteoblastic cells and spleen cells, the target cells of M-CSF are probably osteoclast progenitors. Signal transduction pathways through $\mathrm{M}-\mathrm{CSF}$ receptors have been investigated in bone marrow-derived macrophages and several established cell lines of the monocyte-macrophage lineage. In the M-CSF (CSF-1)-dependent mouse macrophage cell line BAC1.2F5, M-CSF stimulated the rapid tyrosine phosphorylation of several, predominantly cytoplasmic, proteins $(18,28$, 29 ) that was followed by serine phosphorylation of the cytoplasmic protooncogene product, RAF-1, and activation of the RAF-1-associated serine kinase (30). Using a murine macrophage cell line, P388D1, Varticovski et al. reported that M-CSF receptors activated phosphatidylinositol-3 kinase, which may play an important role in the signal transduction pathway of M-CSF (31). It was also shown that M-CSF was required by bone marrow-derived macrophages during the Gl phase to ensure both cell survival and entry into the $S$ phase, but was no longer required after cells had entered the $S$ phase (32). More recently, Matsushime et al. (33) reported that regulators of the G1/S transition could be cyclin-like proteins whose expression was regulated by M-CSF. It is not known whether such M-CSF signal transduction pathways are also important in the development of osteoclasts. Most of the work so far reported points to an important role for M-CSF as a mitogen of monocyte-macrophage lineage cells, but very little is known about the mechanism of action of M-CSF in cell differentiation. Therefore, the in vitro system for osteoclast development used in this study will be a useful model for investigating the role of M-CSF in cell differentiation. Further studies are needed to elucidate the mechanism underlying the signal transduction induced by $\mathbf{M}$ CSF-activated tyrosine kinase and osteotropic hormones in osteoclast development.

\section{Acknowledgments}

This work was supported by grants-in-aid $(02454429,03454437)$ from the Ministry of Science, Education, and Culture of Japan, and a grant CA26509 (E. R. Stanley) from the National Institutes of Health.

\section{References}

1. Chambers, T. J. 1989. The origin of the osteoclast. In Peck WA (ed) Bone and Mineral Research. W. A. Peck, editor. Elsevier Science Publishers B.V., Amsterdam. Vol 6:1-25.

2. Burger, E. H., J. W. M. van der Meer, J. S. van de Gevel, L. C. Gribnau, C. W. Thesingh, and R. van Furth. 1982. In vitro formation of osteoclasts from long-term cultures of bone marrow mononuclear phagocytes. J. Exp. Med. 156:1604-1614.

3. Roodman, G. D., K. J. Ibbotson, B. R. MacDonald, T. J. Kuehl, and G. R. Mundy. 1985. 1,25-Dihydroxyvitamin $D_{3}$ causes formation of multinucleated cells with several osteoclast characteristics in cultures of primate marrow. Proc. Natl. Acad. Sci. USA. 82:8213-8217.

4. Kurihara, N., T. Suda, Y. Miura, H. Nakauchi, H. Kodama, Y. Hakeda, and M. Kumegawa. 1989. Generation of osteoclasts from isolated hematopoietic progenitor cells. Blood. 74:1295-1302.

5. MacDonald, B. R., N. Takahashi, L. M. McManus, J. Holahan, G. R. Mundy, and G. D. Roodman. 1987. Formation of multinucleated cells which respond osteotropic hormones in long-term human marrow cultures. Endocrinology. 120:2326-2333.

6. Takahashi, N., T. Akatsu, N. Udagawa, T. Sasaki, A. Yamaguchi, J. M. Moseley, T. J. Martin, and T. Suda. 1988. Osteoblastic cells are involved in osteoclast formation. Endocrinology. 123:2600-2602.

7. Udagawa, N., N. Takahashi, T. Akatsu, H. Tanaka, T. Sasaki, T. Nishijima, T. Koga, T. J. Martin, and T. Suda. 1990. Origin of osteoclasts: mature monocytes and macrophages are capable of differentiating into osteoclasts under a suitable microenvironment prepared by bone marrow-derived stromal cells. Proc. Natl. Acad. Sci. USA. 87:7260-7264.

8. Felix, R., M. G. Cecchini, W. Hofstetter, P. R. Elford, A. Stutzer, and H. Fleisch. 1990. Impairment of macrophage colony-stimulating factor production and lack of resident bone marrow macrophages in the osteopetrotic op/op mouse. J. Bone Miner. Res. 5:781-789.

9. Wiktor-Jedrzejczak, W., A. Bartocci, A. W. Ferrante, Jr., A. Ahmed-Ansari, K. W. Sell, J. W. Pollard, and E. R. Stanley. 1990. Total absence of colonystimulating factor 1 in the macrophage-deficient osteopetrotic (op/op) mouse. Proc. Natl. Acad. Sci. USA. 87:4828-4832.

10. Yoshida, H., S. Hayashi, T. Kunisada, M. Ogawa, S. Nishikawa, H. Okamura, T. Sudo, L. D. Shultz, and S. Nishikawa. 1990. The murine mutation osteopetrosis is in the coding region of macrophage colony stimulating factor gene. Nature (Lond.). 345:442-444.

11. Felix, R., M. G. Cecchini, and H. Fleisch. 1990. Macrophage colony stimulating factor restores in vivo bone resorption in the $o p / o p$ osteopetrotic mouse. Endocrinology. 127:2592-2594.

12. Kodama, H., A. Yamasaki, M. Nose, S. Niida, Y. Ohgame, M. Abe, M. Kumegawa, and T. Suda. 1991. Congenital osteoclast deficiency in osteopetrotic $(o p / o p)$ mice is cured by injection of macrophage colony-stimulating factor. $J$. Exp. Med. 173:269-272.

13. Wiktor-Jedrzejczak, W., E. Urbanowska, S. L. Aukerman, J. W. Pollard, E. R. Stanley, P. Ralph, A. A. Ansari, K. W. Sell, and M. Szperl. 1991. Correction by CSF-1 of defects in the osteopetrotic op/op mouse suggests local, developmental, and humoral requirements for this growth factor. Exp. Hematol. (NY). 19:1049-1054.

14. Takahashi, N., N. Udagawa, T. Akatsu, H. Tanaka, Y. Isogai, and T. Suda. 1991. Deficiency of osteoclasts in osteopetrotic mice is due to a defect in the local microenvironment provided by osteoblastic cells. Endocrinology. 128:1792-1796.

15. MacDonald, B. R., G. R. Mundy, E. A. Clark, T. J. Kuehl, E. R. Stanley, and G. D. Roodman. 1986. Effects of human recombinant CSF-GM and highly purified CSF-1 on the formation of multinucleated cells with osteoclast characteristics in long term bone marrow cultures. J. Bone Miner. Res. 1:227-233.

16. Takahashi, N., N. Udagawa, T. Akatsu, H. Tanaka, M. Shionome, and T. Suda. 1991. Role of colony-stimulating factors in osteoclast development. $J$. Bone Miner. Res. 6:977-985.

17. Stanley, E. R. 1985. The macrophage colony stimulating factor, CSF-1. In Methods in Enzymology: Immunochemical Techniques. S. P. Colowick and N. O. Kaplan, editors. Harcourt Brace Jovanovich Publications, Cleveland, $\mathrm{OH}$. 116:564-587.

18. Li, W., and E. R. Stanley. 1991. Role of dimerization and modification of the CSF-1 receptor in its activation and internalization during the CSF-1 response. EMBO (Eur. Mol. Biol. Organ.) J. 10:277-288.

19. Nicholson, G. C., J. M. Mosley, P. M. Sexton, F. A. O. Mendelsohn, and T. J. Martin. 1986. Abundant calcitonin receptors in isolated rat osteoclasts. $J$. Clin. Invest. 78:355-360.

20. Takahashi, N., H. Yamana, S. Yoshiki, G. D. Roodman, G. R. Mundy, S. J. Jones, A. Boyde, and T. Suda. 1988. Osteoclast-like cell formation and its regulation by osteotropic hormones in mouse bone marrow cultures. Endocrinology. 122:1373-1382.

21. Takahashi, N., T. Akatsu, T. Sasaki, G. C. Nicholson, J. M. Moseley, T. J. Martin, and T. Suda. 1988. Induction of calcitonin receptor by $1 \alpha, 25(\mathrm{OH})_{2} \mathrm{D}_{3}$ in osteoclast-like multinucleated cells formed from mouse bone marrow cells. Endocrinology. 123:1504-1510.

22. Scheven, B. A. A., E. H. Burger, E. W. M. Kawilarang-de Haas, A. M. Wassenaar, and P. J. Nijweide. 1985. Effects of ionizing irradiation on formation and resorbing activity of osteoclasts in vitro. Lab. Invest. 53:72-79. 
23. Stanley, E. R., D. M. Chen, and H. S. Lin. 1978. Induction of macrophage production and proliferation by a purified colony stimulating factor. Nature (Lond.). 274:168-170.

24. Corboz, V. A., M. G. Cecchini, R. Felix, H. Fleisch, G. van der Pluijim, and W. G. M. Lowik. 1992. Effect of macrophage colony-stimulating factor on in vitro osteoclast generation and bone resorption. Endocrinology. 130:437-442.

25. Hattersley, G., J. Owens, A. M. Flanagan, and T. J. Chambers. 1991. Macrophage colony stimulating factor (M-CSF) is essential for osteoclast formation in vitro. Biochem. Biophys. Res. Commun. 177:526-531.

26. Sherr, C. J., C. W. Rettenmier, R. Sacca, M. F. Roussel, A. T. Look, and E. R. Stanley. 1985 . The $c-f m s$ proto-oncogene product is related to the receptor for the mononuclear phagocyte growth factor, CSF-1. Cell. 41:665-676.

27. Kodama, H., M. Ose, S. Niida, and A. Yamasaki. 1991. Essential role of macrophage colony-stimulating factor in the osteoclast differentiation supported by stromal cells. J. Exp. Med. 173:1291-1294.

28. Sengupta, A., W.-K. Liu, Y.-G. Yeung, D. C.-Y. Yeung, A. R. Frackelton, and E. R. Stanley. 1988. Identification and subcellular localization of protein that are rapidly phosphorylated in tyrosine in response to colony stimulating factor 1 . Proc. Natl. Acad. Sci. USA. 85:8062-8066.

29. Downing, J. R., C. W. Rettenmier, and C. J. Sherr. 1988. Ligand-induced tyrosine kinase activity of the colony stimulating factor- 1 receptor in a murine macrophage cell line. Mol. Cell. Biol. 8:1795-1799.

30. Baccarini, M., D. M. Sabatini, H. App, U. R. Rapp, and E. R. Stanley. 1990. Colony stimulating factor-1 (CSF-1) stimulates temperature dependent phosphorylation and activation of the RAF-1 protooncogene product. $E M B O$ (Eur. Mol. Biol. Organ.) J. 9:3649-3657.

31. Varticovski, L., B. Druker, D. Morrison, L. Cantley, and T. Robert. 1989. The colony stimulating factor-1 receptor associates with and activates phosphatidylinositol-3 kinase. Nature (Lond.). 342:699-702.

32. Tushinski, R. J., and E. R. Stanley. 1985. The regulation of mononuclear phagocyte entry into $\mathrm{S}$ phase by the colony stimulating factor CSF-1. J. Cell. Physiol. 122:221-228.

33. Matsushime, H., M. F. Roussel, R. Ashmun, and C. J. Sherr. 1991. Colony-stimulating factor 1 regulates novel cyclins during the $\mathrm{Gl}$ phase of the cell cycle. Cell. 65:707-713. 